\title{
PENGUKURAN TRANSPARANSI KEUANGAN DAERAH BERBASIS WEBSITE PADA KABUPATEN/KOTA DI INDONESIA
}

\author{
Muhammad Rizki Alwahidi*1, Darwanis ${ }^{* 2}$ \\ ${ }^{1,2}$ Program Studi Akuntansi Fakultas Ekonomi dan Bisnis Universitas Syiah Kuala \\ e-mail: rizkialwahidi@gmail.com*1, darwanis.fe@ unsyiah.ac.id ${ }^{* 2}$
}

\begin{abstract}
Abstrak
The purpose of this study was to measure the level of regional financial transparency and see the correlations between the wealth of the local government and BPK's opinion on the level of regional financial transparency in districts / cities in Indonesia. The sample taken in this study is probability sampling with Slovin method. The number of samples used in this study is 224 districts / cities. The data obtained were analyzed using Simple Pearson correlation method. The results of this study indicate that the average level of regional financial transparency in districts / cities in Indonesia is 18.85\%. The highest value is $71 \%$ obtained by Natuna Regency and the lowest value is 2.09 obtained by 48 regencies / cities in Indonesia. The results of this study also show that the level of local government wealth and BPK's Opinion have a very low relationship to the level of regional financial transparency.
\end{abstract}

Keywords: the level of regional financial transparency, wealth of the local government, BPK's opinion

\section{Pendahuluan}

Intruksi Presiden Nomor 03 Tahun 2003 tentang Kebijakan dan Strategi Nasional Pengembangan EGovernment mengintruksikan kepada masing-masing instansi di bawah naungan pemerintah baik pusat maupun daerah agar membuat sebuah situs web yang bertujuan untuk mengenalkan potensi daerahnya, meningkatkan pelayanan publik yang lebih efektif, dan juga memberikan informasi yang cepat dan mudah bagi publik (Nosihana \& Yaya, 2016). E-government diharapkan mampu menciptakan sebuah tata kelola pemerintahan yang baik yang dan bersih (Hermana, Tarigan, Medyawati, \& Silfianti, 2012).

Untuk menindaklanjuti Intruksi Presiden Nomor 03 Tahun 2003 tentang Kebijakan dan Strategi Nasional Pengembangan E-Government, maka pada tahun 2008 dikeluarkan Undang-Undang Nomor 14 Tahun 2008 tentang Keterbukaan Informasi Publik. Dalam Undang-Undang tersebut dinyatakan bahwasanya setiap badan publik, baik pemerintah daerah maupun pemerintah pusat wajib untuk mempublikasikan setiap program dan kegiatan yang telah dilaksanakan (Ritonga \& Syamsul, 2016). Keterbukaan informasi publik yang dimaksud ialah bahwa seluruh informasi yang dipublikasi ataupun diterbitkan dapat diakses dan diperoleh secara mudah dan cepat oleh masyarakat (Latief \& Mutiarin, 2016). Hal ini selaras dengan yang dinyatakan pada pasal 2 ayat 1 dan ayat 3 Undang-Undang Nomor 14 Tahun 2008.

Sebagai bukti upaya serius pemerintah dalam menangani keterbukaan atau transparansi informasi publik, maka diterbitkanlah Intruksi Menteri Dalam Negeri (Mendagri) Nomor 188.52/1797/SJ/2012 tentang Transparansi Pengelolaan Anggaran Daerah (TPAD). Intruksi tersebut memberi pesan kepada seluruh pemerintah daerah agar membuat sebuah Menu Content dengan nama Transparansi Anggaran Pemerintah Daerah di website resmi masing-masing pemerintah daerah (Ritonga \& Syamsul, 2016). Menu content TPAD tersebut nantinya akan berisi informasi seputar dokumen-dokumen yang berkaitan dengan pengelolaan anggaran oleh pemerintah daerah (Agustin, 2014). Transparansi anggaran yang dilakukan oleh pemerintah haruslah disampaikan secara lengkap, tepat waktu, akurat dan mudah dimengerti (Ott, Bronic, Petrušić, \& Stanić, 2017). Transparansi anggaran dianggap sebagai sebuah alat untuk meningkatkan efektifitas dan akuntabilitas publik (Sedmihradská, 2015). Dengan menerbitkan informasi anggaran secara berkala, hal tersebut memungkinkan masyarakat untuk berkontribusi secara 
efisien dalam pengawasan pengelolaan dana publik guna meningkatkan akuntabilitas pemerintah daerah yang berwenang sehingga mampu mengurangi peluang terjadinya korupsi (Ott et al., 2017).

Penelitian yang dilakukan oleh Ritonga dan Syamsul (2016) yang berjudul mengukur transparansi pengelolaan keuangan daerah di Indonesia berbasis website menyimpulkan bahwa masih banyak daerah yang belum menjalankan Intruksi Mendagri. Hal tersebut dibuktikan dengan skor rata-rata transparansi pemerintah provinsi sebesar $16,84 \%$. Skor transparansi pemerintah Provinsi tertinggi dipegang oleh Jawa Tengah, sedangkan skor transparansi terendah dipegang oleh pemerintah Provinsi Sulawesi Barat, Sulawesi Tenggara, Sulawesi Barat, Maluku Utara, dan Papua Barat dengan skor masing-masing sebesar $3,45 \%$. Apabila pengungkapan informasi keuangan di website pemerintah masih tergolong rendah, maka hal tersebut akan berdampak pada tingginya angka korupsi yang terjadi dikarenakan rendahnya pengawasan yang dilakukan oleh masyarakat akibat dari sedikitnya informasi yang disampaikan pemerintah di websitenya (Ott et al., 2017).

Penelitian ini bertujuan untuk mengukur tingkat transparansi pengelolaan keuangan daerah berbasis website, hubungan tingkat transparansi keuangan daerah berbasis website dengan kekayaan pemerintah daerah, hubungan tingkat transparansi keuangan daerah berbasis website dengan opini BPK yang diperoleh Pemerintah Kabupaten dan Kota di Indonesia.

\section{Kajian Pustaka}

\section{Agency Theory}

Agency Theory (teori keagenan) secara umum diartikan sebagai suatu hubungan antara dua pihak ataupun lebih yang berperan menjadi principal (pemberi wewenang) dan agen (penerima wewenang) yang terikat dalam suatu kontrak. Pada dasarnya, teori keagenan ini menjelaskan hubungan antara pemegang saham selaku principal dengan perusahaan sebagai agent (Eisenhardt, 1989). Carr dan Brower (2000) dalam Halim (2006) mengemukakan bahwa sederhananya teori agensi memberikan dua asumsi pilihan yaitu, (1) principal harus mengawasi tindakan agen, dan (2) adanya insentif yang diberikan untuk memotivasi agen dalam menjalankan tugas wewenangnya sesuai dengan harapan prinsipal.
Teori agensi yang umumnya ditemukan di dalam perusahaan sekarang dapat diterapkan di dalam sektor pemerintahan. Halim (2006) mengemukakan bahwa dalam pemerintahan yang dimaksud dengan teori keagenan ialah hubungan kontraktual antara dua pihak, yaitu prinsipal sebagai pemberi wewenang memberikan wewenangnya kepada agen selaku penerima wewenang dengan harapan agen menjalankan wewenang dengan harapan prinsipal. Dalam ruang lingkup pemerintahan, yang bertindak sebagai prinsipal yang akan memberikan wewenang kepada agen ialah rakyat, sedangkan pihak yang bertindak sebagai agen ialah pemerintah daerah maupun pemerintah pusat yang menerima wewenang dari rakyat (Agustin, 2014).

Jensen dan Meckling (1976) dalam Halim (2006) menjelaskan bahwa dalam hubungan keagenan ada kemungkinan besar terjadi penyimpangan yang dilakukan agen terhadap prinsipal karena agen melanggar kontraknya. Untuk mengurangi konflik tersebut, maka prinsipal tentu harus mengeluarkan suatu biaya yang akan digunakan untuk memonitoring tindakan agen. Tujuannya untuk mengetahui apakah agen telah menjalankan wewenangnya sesuai dengan harapan prinsipal. Semakin sulit prinsipal untuk mengawasi agen, maka semakin besar juga biaya yang dikeluarkan untuk memonitoring agen (Agustin, 2014).

Dalam masalah transparansi, teori agensi menjelaskan tentang bagaimana hubungan antara pemerintah selaku agen yang memberikan informasi kepada rakyat selaku principal. Teori ini muncul untuk memahami dan memecahkan permasalahan yang terjadi ketika pemerintah memberikan informasi yang tidak lengkap kepada rakyat. Ketika rakyat mengoptimalkan pengawasan mereka dan mendapatkan data yang relevan dari pemerintah, maka asimteri informasi pun dapat dikurangi (Adriana \& Ritonga, 2018).

\section{Signaling Theory}

Menurut Conelly et al., (2011) signalling theory ialah teori yang menjelaskan tingkah laku antara dua pihak (baik individu maupun organisasi) yang memiliki akses berbeda terhadap suatu informasi. Oleh karena itu, baik pengirim maupun penerima harus mampu mengkondisikan bagaimana cara mereka mengirim (memberi sinyal) suatu informasi kepada 
pihak lain, dan pihak penerima harus mampu menafsirkan pesan atau informasi yang diterima.

Perbedaan akses tersebut memiliki dampak yang serius terhadap pihak yang menerima informasi. Hal tersebut dikarenakan pihak pengirim sinyal memiliki informasi lebih yang tidak disampaikan kepada penerima pesan yang berakibat pada asimetri informasi diantara kedua belah pihak (Akerlof, 1970). Ketika pihak pengirim sinyal mengirimkan informasi yang tidak kredibel dikarenakan adanya asimetri informasi, maka suatu entitas tersebut akan memiliki pandangan terhadap entitasnya (Spence, 1972).

Dalam sektor pemerintahan, teori sinyal tersebut dapat diadopsi dalam tindakan dan komunikasi pemerintah dengan masyarakat. Agustin (2014) menjelaskan ketika pemerintah daerah maupun pemerintah pusat mengirimkan atau mempublikasikan informasi yang dimilikinya secara kredibel maka hal tersebut mampu memberikan sinyal yang baik kepada masyarakat dan juga dapat meningkatkan kepercayaan masyarakat. Tujuan utamanya ialah agar dengan informasi yang dikirim oleh pemerintah, masyarakat mampu untuk menilai wewenang atau amanat yang telah dijalankan pemerintah (Evans \& Patton, 1987).

Hal senada diungkapkan oleh Hilmi dan Martani (2012) bahwa implementasi teori sinyal dalam sektor pemerintah dengan cara menyediakan informasi keuangan yang cermat, pengungkapan informasi kinerja pemerintah secara transparan, peningkatan layanan umum, dan penyampaian prestasi dan kinerja keuangan pemerintah yang disajikan secara menarik mampu meningkatkan minat membaca pengguna. Tindakan sukarela pemerintah dalam mengungkapkan informasi tersebut secara lengkap mengindikasikan bahwa pemerintah memiliki inisiatif untuk mengembangkan tata kelolanya secara transparan sehingga mendapatkan sinyal yang baik dari masyarakat (Nosihana \& Yaya, 2016).

\section{E-government}

E-government secara ringkas dapat dimaknai sebagai penggunaan teknologi informasi dan komunikasi canggih dalam menyelenggarakan pemerintahannya. Sosiawan (2008) mengatakan bahwa yang dimaksud dengan e-government adalah penggunaan teknologi informasi oleh pemerintah yang bertujuan dalam memberikan informasi, pelayanan kepada masyarakat, urusan bisnis dan hal lainnya yang berkaitan dengan pemerintahan. Pada intinya, $e$ government berhubungan dengan penggunaan teknologi informasi dan komunikasi menggunakan internet yang bertujuan untuk meningkatkan akses informasi dan pelayanan kepada masyarakat (Hermana et al., 2012).

Prihanto (2012) mengemukakan bahwa misi $e$ government Indonesia, meliputi: (a) Meningkatkan efisiensi, efektivitas, dan akuntabilitas di seluruh lingkungan pemerintah sektoral dan regional; (b) Meningkatkan kualitas pelayanan publik; (c) Meningkatkan koordinasi antar instansi; dan (d) Mendukung pelaksanaan reformasi birokrasi. Pengembangan e-government diarahkan untuk mencapai 4 (empat) tujuan, yaitu:

a) Pembentukan jaringan informasi dan transaksi pelayanan publik yang memiliki kualitas dan lingkup yang dapat memuaskan masyarakat luas serta dapat terjangkau di seluruh wilayah Indonesia pada setiap saat tidak dibatasi oleh sekat waktu dan dengan biaya yang terjangkau oleh masyarakat.

b) Pembentukan hubungan interaktif dengan dunia usaha untuk meningkatkan perkembangan perekonomian nasional dan memperkuat kemampuan menghadapi perubahan dan persaingan perdagangan internasional.

c) Pembentukan mekanisme dan saluran komunikasi dengan lembaga-lembaga negara serta penyediaan fasilitas dialog publik bagi masyarakat agar dapat berpartisipasi dalam perumusan kebijakan negara.

d) Pembentukan sistem manajemen dan proses kerja yang transparan dan efisien serta memperlancar transaksi dan layanan antar lembaga pemerintah dan pemerintah daerah otonom.

\section{Pengelolaan Keuangan Daerah}

Anggaran Pendapatan dan Belanja Negara (APBN) serta Anggaran Pendapatan dan Belanja Daerah (APBD) merupakan pedoman bagi pemerintah dalam menjalankan pemerintahannya. Tanpa adanya sebuah anggaran maka mustahil suatu pemerintahan dapat berjalan. Anggaran berisi rencana kerja pemerintah yang dideskripsikan dalam satuan uang. Ritonga dan Syamsul (2016) menjelaskan bahwa APBN dan APBD juga merupakan sebuah alat bagi pemerintah dalam menjalankan programnya untuk mensejahterakan rakyatnya dan juga alat utama pemerintah dalam mengorganisir keuangan daerahnya. 
Aturan mengenai keuangan daerah tersebut tertuang dalam Peraturan Pemerintah (PP) Nomor 58 Tahun 2005 tentang Pengelolaan Keuangan Daerah dan Peraturan Menteri Dalam Negeri (Permendagri) Nomor 13 Tahun 2006 tentang Pedoman Pengelolaan Keuangan Daerah. Jika merujuk pada peraturan tersebut, pengelolaan keuangan daerah memiliki tahapan-tahapan yang diawalai dari perencanaan, pelaksanaan, penatausahaan, pelaporan, pertanggungjawaban, hingga pengawasan keuangan daerah (Ritonga \& Syamsul, 2016).

\section{Transparansi}

Araujo dan Tejedo-Romero (2016) menjelaskan bahwa transparansi berkaitan erat dengan ketersediaannya informasi yang dapat diakses dan digunakan oleh pemangku kepentingan lainnya. Sedmihradská (2015) mengungkpakan bahwa tingkat transparansi yang tinggi ditandai dengan peningkatan publikasi dokumen anggaran oleh pemerintah, hal tersebut akan mengarah peningkatan akuntabilitas pemerintah yang lebih baik kedepannya dan membantu pemangku kepentingan atas informasi tersebut dalam mengambil tindakan. Oleh karena itu, publikasi dokumen tersebut harus dilakukan secara tepat waktu, lengkap, dan mudah dipahami (da Cruz, Tavares, Marques, Jorge, \& de Sousa, 2016).

Araujo dan Tejedo-Romero (2016) menjelaskan bahwa transparansi erat berkaitan dengan pengungkapan informasi oleh pemerintah mengenai kebijakan, proses, fungsi dan kinerja pemerintah itu sendiri. Pengungkapan informasi itu sendiri diharapkan mampu untuk mengurangi kepentingan pribadi pemerintah sehingga pemerintah mampu bertanggungjawab atas tindakan apapun yang diambil dan menjelaskan alasannya kepada publik (da Cruz et al., 2016).

Dalam konteks pengelolaan keuangan daerah di Indonesia, definisi transparansi dijelaskan di dalam Peraturan Pemerintah Nomor 24 Tahun 2005 tentang Standar Akuntansi Pemerintahan yang kemudian diperbaharui dengan Peraturan Pemerintah Nomor 71 Tahun 2010 Tentang Standar Akuntansi Pemerintahan yaitu: Memberikan informasi keuangan yang terbuka dan jujur kepada masyarakat berdasarkan pertimbangan bahwa masyarakat memiliki hak untuk mengetahui secara terbuka dan menyeluruh atas pertanggungjawaban pemerintah dalam pengelolaan sumber daya yang dipercayakan kepadanya dan ketaatannya pada peraturan perundang-undangan.

Dalam Peraturan Pemerintah Nomor 58 tentang Pengelolaan Keuangan Daerah, dinyatakan bahwa keuangan daerah harus dikelola secara tertib, taat pada peraturan perundang-undangan, efisien, ekonomis, efektif, transparan, dan bertanggung jawab dengan memperhatikan asas keadilan, kepatuhan, dan manfaat untuk masyarakat (Nurhayati, 2017).

\section{Indeks Transparansi Berdasarkan Open Budget Survey Yang Dilakukan International Budget Partnership}

International Budget Partnership atau yang disingkat dengan IBP merupakan sebuah lembaga independen internasional yang bergerak dibidang transparansi anggaran dengan melakukan surveinya yang dikenal dengan Open Budget Survey di berbagai belahan dunia. IBP bekerjasama dengan masyarakat sipil di seluruh dunia untuk menganalisis anggaran dan menggunakannya untuk meningkatkan tata kelola yang efektif dan juga mampu mengurangi kemiskinan.

Open Budget Survey yang dilakukan oleh IBP bertujuan untuk mengukur tingkat keterbukaan informasi pengelolaan keuangan pemerintah di berbagai negara di seluruh dunia (Ritonga \& Syamsul, 2016). Adapun survei dilakukan dengan menggunakan bukti dokumen dan kriteria yang bersifat objektif untuk mengetahui apakah pemerintah telah memberikan akses informasi yang lengkap kepada masyarakat secara tepat waktu (Ritonga \& Syamsul, 2016).

\section{Metode Penelitian Desain Penelitian}

Tujuan studi yang digunakan dalam penelitian ini adalah bersifat studi deskriptif. Tujuan studi penelitian ini dilakukan adalah untuk mendeskripsikan tingkat transparansi pengelolaan keuangan daerah yang telah dijalankan oleh Pemkab/Pemkot berdasarkan Intruksi Mendagri Nomor 188.52/1797/SJ Tahun 2012 dan mendeskripsikan hubungan antara tingkat Opini BPK dan tingkat pendapatan Kabupaten/Kota di Indonesia terhadap tingkat transparansi pengelolaan keuangan daerahnya .

Strategi penelitian dalam penelitian ini menggunakan strategi penelitian observasi (pengamatan). Dalam penelitian ini, peneliti akan 
mengamati website Pemkab/Pemkot di Indonesia untuk mengetahui apakah 12 dokumen pengelolaan anggaran dalam Intruksi Mendagri Nomor 188.52/1797/SJ Tahun 2012 tersedia atau tidak tersedia. Situasi studi pada penelitian ini adalah situasi tidak diatur atau situasi alami. Tingkat intervensi dalam penelitian ini adalah intervensi minimal. Unit analisis dalam penelitian ini adalah 12 (dua belas) dokumen anggaran tahun 2016 yang terdapat di menu content dengan judul Transparansi Pengelolaan Anggaran Daerah (TPAD) di website resmi Pemkab/Pemkot di Indonesia. Dalam penelitian ini horizon waktu yang digunakan adalah cross sectional atau one-shoot. Hal ini dikarenakan peneliti hanya mengumpulkan data dalam satu periode saja yaitu pada tahun 2016.

\section{Populasi dan Sampel Penelitian}

Populasi dalam penelitian ini adalah seluruh Kabupaten/Kota di Indonesia yang berjumlah 508 Kabupaten/Kota. Pengambilan sampel pada penelitian ini menggunakan jenis probability sampling. Teknik pengambilan sampelnya menggunakan teknik simple random sampling. Dalam menentukan jumlah sampel dalam penelitian ini peneliti menggunakan rumus Slovin. Jumlah sampel dalam penelitian ini sebanyak 224 kabupaten/kota di Indonesia.

\section{Sumber dan Teknik Pengumpulan Data}

Jenis data yang digunakan pada penelitian ini ialah data sekunder. Data sekunder adalah data yang diperoleh melalui sumber yang telah ada dan tidak perlu dikumpulkan sendiri oleh peneliti. Data yang digunakan adalah dokumen pengelolaan anggaran yang sesuai dengan Intruksi Mendagri Nomor 188.52/1797/SJ Tahun 2012. Sumber data dalam penelitian ini diperoleh melalui situs resmi masingmasing Pemkab/Pemko yang didapat melalui checklist dokumen anggaran berdasarkan Intruksi Mendagri Nomor 188.52/1797/SJ Tahun 2012. Alamat resmi website tiap-tiap Pemkab/Pemkot dapat diakses melalui situs www.depdagri.go.id. Teknik pengumpulan data yang digunakan dalam penelitian ini menggunakan studi kepustakaan dan observasi.

\section{Definisi Operasional dan Pengukuran}

Adriana dan Syamsul (2018) mendefinisikan transparansi pengelolaan keuangan daerah sebagai suatu bentuk keterbukaan informasi terkait kebijakankebijakan terkait anggaran (keuangan daerah) yang dilakukan oleh pemerintah daerah sehingga dapat diketahui dan diawasi oleh publik (masyarakat) dan pemangku kepentingan lainnya, mulai dari tahap perencanaan hingga tahap pelaporan dan pertanggungjawaban pelaksanaan APBD. Dokumen yang dilakukan check list dalam penelitian ini berjumlah sebanyak 12 (dua belas) dokumen yang dipersyaratkan merujuk pada Intruksi Menteri Dalam Negeri Nomor 188.52/1797/SJ Tahun 2012 tentang Transparansi Pengelolaan Anggaran Daerah.

Selanjutnya, terdapat 4 (empat) kriteria utama yang dilihat dalam pengelolaan keuangan daerah yaitu ketersediaan, aksesibilitas konten, ketepatan waktu, dan frekuensi pengungkapan dokumen. Ketersediaan konten artinya konten yang ingin diteliti tersedia di dalam menu content TPAD di website. Aksesibilitas konten artinya konten selain tersedia di dalam menu content TPAD, konten yang ingin diteliti harus bisa diakses atau diunduh oleh publik. Ketepatan waktu artinya konten yang diunggah selain tersedia dan bisa diakses, konten tersebut harus diunggah secara tepat waktu berdasarkan masa tenggang penggunggahan yang ditetapkan dalam Peraturan Menteri Nomor 13 Tahun 2006 tentang Pedoman Pengelolaan Keuangan Daerah. Frekuensi pengungkapan dokumen yaitu berhubungan ketersedian informasi transparansi keuangan daerah selama periode tertentu. Frekuensi pengungkapan dokumen yang dilihat dalam penelitian adalah 5 tahun sebelumnya yaitu hingga Tahun 2013.

Adapun jika informasi yang diunggah tidak sesuai dengan waktu yang dipersyaratkan, maka informasi tersebut dianggap tidak tepat waktu. Informasi yang disajikan secara tepat waktu akan lebih bermanfaat digunakan dalam pengambilan keputusan

\section{Teknik Analisis Data}

Teknis analisis data yang digunakan dalam penelitian adalah analisis kualitatif deskriptif dan Analisis Korelasi Sederhana. Analisis dalam penelitian ini berfokus pada hasil indeks transparansi pengelolaan keuangan daerah yang telah diukur oleh peneliti dan hasil statistik deskriptif. Statistik deskriptif dalam penelitian ini digunakan melihat tingkat transparansi daerah secara umum dan berdasarkan masing-masing indikator. Tujuan analisis deskriptif adalah untuk memberikan deskripsi atau 
gambaran data yang telah diteliti sehingga mudah dipahami oleh orang yang membacanya.

Analisis korelasi dalam penelitian ini bertujuan untuk melihat hubungan antara tingkat Transparansi Keuangan Daerah yang diterima oleh pemerintah kabupaten/kota dengan tingkat Kekayaan Pemda yang dimiliki dan Opini BPK yang diterima. Dalam SPSS ada tiga metode korelasi sederhana (bivariate correlation) diantaranya Pearson Correlation, Kendall's tau-b, dan Spearman Correlation. Pada penelitian ini peneliti menggunakan metode Pearson Correlation.

\section{Hasil dan Pembahasan}

\section{Hasil Penelitian}

\section{Transparansi Keuangan Daerah Pada}

\section{Kabupaten/Kota di Indonesia}

Berdasarkan hasil pengukuran Indeks Transparansi Keuangan Daerah, terdapat 6 kabupaten/kota di Indonesia yang mendapatkan klasifikasi Indeks Transparansi Keuangan Daerah Substansial dengan interval nilai indeks antara 61-80. Kabupaten/kota yang menduduki klasfikasi adalah Kabupaten Gorontalo (71,00\%), Kabupaten Trenggalek (69,00\%), Kabupaten Kudus $(69,00 \%)$, Kabupaten Gorontalo (68,75\%), Kota Banda Aceh

Tabel 4.1

Korelasi Transparansi Keuangan Daerah dan Kekayaan Pemda

\begin{tabular}{|cc|c|c|}
\hline \multirow{3}{*}{ Transparansi } & Transparansi & Kekayaan Pemda \\
\cline { 2 - 4 } & Pearson Correlation & 1 &, 091 \\
\cline { 2 - 4 } & Sig. (2-tailed) & &, 175 \\
\cline { 2 - 4 } Kekayaan Pemda & $\mathrm{N}$ & 224 & 224 \\
\cline { 2 - 4 } & Pearson Correlation &, 091 & 1 \\
\cline { 2 - 4 } & Sig. (2-tailed) &, 175 & 224 \\
\hline
\end{tabular}

Data diolah (2018)

\section{Hubungan Transparansi Keuangan Daerah dan Opini BPK}

Analisis korelasi ini bertujuan untuk mengetahui seberapa besar hubungan antara Transparansi Keuangan Daerah dengan Opini BPK. Hasil Pearson Correlation pada tabel 4.7 menunjukkan nilai 0,057
$(62,50 \%)$ dan Kabupaten Kebumen $(62,50 \%)$. Jika berpedoman dengan klasifikasi tingkat keterbukaan informasi anggaran yang dikeluarkan oleh International Budget Partnership maka 6 kabupaten/kota tersebut telah masuk dalam kategori Kelompok Sufficient.

Nilai jumlah kesuluruhan indeks transparansi keuangan ialah sebesar 2430,10 dengan nilai mean sebesar 10,85. Mean pada tabel menunjukkan nilai rata-rata indeks transparansi keuangan daerah di Indonesia. 195 kabupaten/kota mendapatkan nilai minimal indeks transparansi keuangan daerah yaitu 2,09. Sedangkan nilai maksimal diperoleh oleh Kabupaten Natuna dengan nilai indeks 71,00.

\section{Hubungan Transparansi Keuangan Daerah dengan Kekayaan Pemerintah Daerah}

Hasil Pearson Correlation yang menunjukkan nilai 0,091 yang artinya korelasi diantara Transparansi Keuangan Daerah dan Kekayaan Pemerintah Daerah "Sangat Rendah". Artinya tinggi atau rendahnya nilai indeks Transparansi Keuangan Daerah hampir tidak memiliki hubungan sama sekali dengan Kekayaan Pemerintah Daerah. 
Tabel 4.7

Korelasi Transparansi Keuangan Daerah dan Opini BPK

\begin{tabular}{|cc|c|c|}
\hline \multirow{3}{*}{ Transparansi } & Transparansi & Opini BPK \\
\cline { 2 - 4 } & Pearson Correlation & 1 &, 057 \\
\cline { 2 - 4 } & Sig. (2-tailed) & &, 396 \\
\cline { 2 - 4 } Opini BPK & $\mathrm{N}$ & 224 & 224 \\
\cline { 2 - 4 } & Pearson Correlation &, 057 & 1 \\
\cline { 2 - 4 } & Sig. (2-tailed) &, 396 & 224 \\
\hline
\end{tabular}

Data diolah (2018)

\section{Pembahasan}

\section{Transparansi Keuangan Daerah pada Kabupaten/Kota di Indonesia}

Rendahnya nilai indeks transparansi keuangan daerah yang didapatkan oleh pemerintah kabupaten/kota menyimpulkan bahwa masih banyak pemerintah kabupaten/kota yang masih menganggap informasi keuangan adalah sesuatu yang bersifat rahasia dan dipublikasikan publik. Hasil penelitian ini juga menunjukkan bahwa pemerintah masih menganggap informasi pengelolaan keuangan daerah bersifat dan tidak boleh dipublikasi secara umum kepada publik.

Tidak adanya sanksi bagi website-website pemda tersebut mungkin bisa menjadi penyebab utama keenggan pemerintah dalam mempublikasikan dokumen-dokumen pengelolaan anggaran daerah. Rendahnya indeks transparansi keuangan daerah di Indonesia mesti disikapi dengan cara memberikan teguran, peringatan dan sanksi yang tegas mengingat publik juga memiliki hak untuk memiliki dan mengetahui informasi keuangan tersebut. Sehingga publik dapat lebih ikut andil dalam pengawasan pengelolaan keuangan daerah.

\section{Hubungan Transparansi Keuangan Daerah dan Kekayaan Pemerintah Daerah}

Hasil penelitian ini menunjukkan bahwa transparansi keuangan daerah dan kekayaan pemda memiliki hubungan yang sangat rendah. Artinya tinggi atau rendahnya transparansi keuangan daerah yang diperoleh suatu daerah memiliki hubungan yang sangat rendah. Tingkat korelasinya ialah hanya sebesar 0,091 .

Hal ini menjelaskan bahwa tingkat kekayaan pemerintah daerah yang tinggi belum tentu menjalin tingkat transparansi keuangan daerah. Kekayaan pemda yang tinggi belum tentu mampu memberikan dampak langsung masyarakat membutuhkan informasi pengelolaan keuangan daerah pada website resmi pemda. Hal tersebut bisa disebabkan karena tidak semua masyarakat Indonesia mampu memahami informasi pengelolaan anggaran daerah yang dipublikasi oleh pemerintah kabupaten/kota di websitenya, hanya sebagian kalangan yang mampu memahami informasi tersebut.

\section{Hubungan Transparansi Keuangan Daerah dan Opini BPK}

Penelitian ini menggunakan variabel Opini BPK untuk melihat tingkat korelasi antara tingkat transparansi keuangan daerah yang diterima dengan Opini BPK yang diterima. Hasil penelitian ini juga menunjukkab bahwa tingkat transparansi keuangan daerah dan Opini BPK memiliki hubungan yang sangat rendah yaitu sebesar 0,057 . Artinya tinggi atau rendahnya tingkat transparansi keuangan daerah yang diperoleh sangat kecil kemungkinannya disebabkan oleh Opini BPK yang diterima.

Hampir seluruh kabupaten/kota dari 224 kabupaten/kota yang diteliti mendapatkan Opini Wajar Tanpa Pengecualian (WTP) akan tetapi memiliki tingkat transparansi keuangan daerah yang buruk. Bahkan pemerintah Kabupaten Natuna yang mendapakan Opini Wajar Dengan Pengecualian menduduki rangking satu dengan indeks $71,00 \%$. Hal ini sejalan dengan yang dijelaskan oleh Nosihana dan Yaya (2016) bahwa Opini WTP tidak selalu mampu mendorong pemerintah kabupaten/kota untuk mengungkap dokumen Intruksi Mendagri Nomor 188.52/1797/SJ tahun 2012 tentang Transparansi Pengelolaan Anggaran Daerah.

Hal ini dikarenankan Opini WTP tidak selalu mengindikasikan bahwa pemerintah telah memiliki kinerja dan akuntabilitas yang buruk. Ada banyak aspek lain yang digunakan untuk mengukur kinerja 
dan akuntabilitas suatu pemerintah.

\section{Kesimpulan, Keterbatasan, dan Saran Kesimpulan}

1. Rata-rata tingkat transparansi keuangan daerah di Indonesia berdasarkan 224 kabupaten/kota yang diteliti adalah 10,85. Nilai tertinggi Indeks Tranparansi Keuangan Daerah didapatkan oleh Kabupaten Natuna dengan nilai indeks transparansi keuangan daerah 71. Nilai terendah Indeks Transparansi Keuangan Daerah adalah 2,09. Nilai Indeks Transparansi Keuangan Daerah terendah didapatkan oleh 48 kabupaten/kota di Indonesia dari 224 kabupaten/kota di Indonesia yang dijadikan sampel.

2. Kekayaan Pemda memiliki hubungan yang sangat rendah dengan Tingkat Transparasi Keuangan Daerah yang diterima pemerintah kabupaten/kota.

3. Opini BPK memiliki hubungan yang sangat rendah dengan Tingkat Transparasi Keuangan Daerah yang diterima pemerintah kabupaten/kota.

\section{Keterbatasan}

Penelitian ini memiliki keterbatasan yang memerlukan perbaikan dan pengembangan dalam penelitian-penelitian berikutnya. Adapun keterbatasan yang dihadapi adalah banyaknya website-website pemerintah kabupaten/kota yang tidak dapat diakses sehingga observasi yang dilakukan pun menjadi sedikit terganggu dan waktu yang digunakan yaitu hanya 1 tahun saja.

\section{Saran}

1. Bagi pemerintah kabupaten/kota terutama bagi yang tidak sama sekali mempublikasikan 12 dokumen Transparansi Pengelolaan Anggaran Daerah hendaknya untuk segera mempublikasikan dokumen-dokumen yang diintruksikan tersebut ke dalam websitenya masing-masing. Bagi Pemerintah kabupaten/kota yang telah mempublikasikan baik seluruh maupun sebagian dari 12 dokumen tersebut hendaknya untuk mencantumkan tanggal upload ataupun tanggal penetapan sebuah dokumen tersebut. Karena salah satu kriteria dokumen yang dijadikan indicator penilaian adalah ketepatan waktu.

2. Bagi peneliti selanjutnya diharapkan mampu untuk melanjutkan penelitian ke ranah yang lebih rinci, sebaiknya menggunakan lebih banyak website pemerintah kabupaten/kota dan juga menambahkan website pemerintah provinsi untuk dilakukan observasi.

3. Penelitian selanjutnya dapat menggunakan variabel-variabel lain yang berhubungan dengan tingkat transparansi keuangan daerah. Sehingga dapat diketahui variabel yang berhubungan tinggi atau rendahnya nilai indeks yang diterima Pemda

\section{Daftar Pustaka}

Abdullah, A. H. dan S. (2006). Hubungan Dan Masalah Keagenan Di Pemerintah Daerah: Sebuah Peluang Penelitian Anggaran dan Akuntansi1, 2, 53-64.

Adriana, A., \& Ritonga, I. T. (2018). Analysis of Local Financial Management Transparency Based on Websites on Local Government in Java. Jurnal Dinamika Akuntansi, 10(1), 13-26. https://doi.org/DOI:

http://dx.doi.org/10.15294/jda.v10i1.12558

Agustin, H. (2014). Publikasi Dokumen Pengelolaan Anggaran pada Website Pemkab / Pemkot di Propinsi Sumatera Barat. In Seminar Nasional Aplikasi Teknologi Informasi (SNATI) (pp. 712). Yogyakarta.

Akerlof, G. A. (1970). The Market for "Lemons": Quality Uncertainty and the Market Mechanism. The Quarterly Journal of Economics, 84(3), 488. https://doi.org/10.2307/1879431

Araujo, J. F. F. E. de, \& Tejedo-Romero, F. (2016). Local government transparency index: determinants of municipalities' rankings.

International Journal of Public Sector Management, 29(4), 327-347. https://doi.org/10.1108/JJPSM-11-2015-0199

Carr, J., \& Brower, R. (2000). Principled Opportunism: Evidence from the Organizational Middle. Public Administration Quarterly, 24(Spring), 109-138.

Connelly, B. L., Certo, S. T., Ireland, R. D., \& Reutzel, C. R. (2011). Signaling theory: A review and assessment. Journal of Management, $37(1)$, $39-67$. https://doi.org/10.1177/0149206310388419

da Cruz, N. F., Tavares, A. F., Marques, R. C., Jorge, S., \& de Sousa, L. (2016). Measuring Local Government Transparency. Public Management 
Review, 18(6), 866-893. https://doi.org/10.1080/14719037.2015.1051572 Eisenhardt, K. M. (1989). Agency Theory: An Assessment and Review. Academy of Management, 14(1), 57-74. Retrieved from http://www.jstor.org/stable/258191

Evans, J. H., \& Patton, J. M. (1987). Signaling and Monitoring in Public-Sector Accounting. Journal of Accounting Research, 25(1987), 130-158. https://doi.org/10.2307/2491084

Hermana, B., Tarigan, A., Medyawati, H., \& Silfianti, W. (2012). E-Government Implementation in Indonesia: Financial Transparency on the Web. $3 r d$ - International Conference on E-Education, E-Business, E-Management and E-Learning IPEDR, 27, 194-199.

Hilmi, A. Z., \& Martani, D. (2012). Analisis FaktorFaktor yang Mempengaruhi Tingkat Pengungkapan Laporan Keuangan Pemerintah Provinsi. In Simposium Nasional Akuntansi XV (pp. 1-26).

Jensen, M., \& Meckling, W. (1976). Theory of the firm: managerial behavior, agency costs, and ownership structure. The Economic Nature of the Firm, 283-303. https://doi.org/10.1017/CBO9780511817410.02 3

Latief, F., \& Mutiarin, D. (2016). Transparansi Pengelolaan Anggaran Daerah Di Satuan Kerja Perangkat Daerah (SKPD) Kabupaten Bulukumba. Jurnal Ilmu Pemerintahan Dan Kebijakan Publik.

Nosihana, A., \& Yaya, R. (2016). Internet Financial Reporting dan Faktor-Faktor yang Mempengaruhinya Pada Pemerintah Kota dan Kabupaten Di Indonesia. Jurnal Dinamika Akuntansi Dan Bisnis, 3(2), 89-104.

Nurhayati. (2017). Analisis Teori Transparansi Pengelolaan Keuangan Daerah di Indonesia. Trias Politika, 1(2), 36-54.

Ott, K., Bronic, M., Petrušić, M., \& Stanić, B. (2017). Budget transparency in Croatian counties, cities and municipalities (November 2016 - March 2017). Institute of Public Finance, 385(112), 113. https://doi.org/10.3326/nle.2017.112

Prihanto, I. G. (2012). Analisis Implementasi EGovernment Pada Pemerintah [ Analysis of the Implementation of E-Government on Regional
Government Level in Indonesia ], 1-16.

Ritonga, I. T., \& Syamsul. (2016). Mengukur transparansi pengelolaan keuangan daerah di Indonesia: berbasis website. Jurnal Akuntansi \& Auditing Indonesia, 20(2). https://doi.org/http://dx.doi.org/10.20885/jaai.vo 120.iss2.art4 P

Sedmihradská, L. (2015). Budget Transparency in Czech Local Government. Procedia Economics and Finance, 25(May), 598-606. https://doi.org/10.1016/S2212-5671(15)00774-1

Sosiawan, E. A. (2008). Tantangan Dan Hambatan Dalam Implementasi E-Government Di Indonesia. In Seminar Nasional Informatika (Vol. 2008, pp. 99-108).

Spence, M. (1972). Job market signaling. Quarterly Journal of Economics, 87(3), 355-374. 